\title{
The Health Benefiting Mechanisms of Virgin Olive Oil Phenolic Compounds
}

\author{
Lisa Parkinson $^{1, *}$ and Sara Cicerale ${ }^{2}$ \\ 1 Department of Medical and Health Science, Swinburne University, Hawthorn, VIC 3122, Australia \\ 2 School of Exercise and Nutrition Sciences, Centre for Advanced Sensory Science (CASS), Deakin University, \\ Burwood, VIC 3125, Australia; sara.cicerale@deakin.edu.au \\ * Correspondence: ljparkinson@swin.edu.au; Tel.: +61-3-9214-8885 \\ Academic Editor: Pedro Mena \\ Received: 14 September 2016; Accepted: 12 December 2016; Published: 16 December 2016
}

\begin{abstract}
Virgin olive oil (VOO) is credited as being one of the many healthful components associated with the Mediterranean diet. Mediterranean populations experience reduced incidence of chronic inflammatory disease states and VOO is readily consumed as part of an everyday Mediterranean dietary pattern. $\mathrm{VOO}$ is rich in phenolic compounds and the health promoting benefits of these phenolics are now established. Recent studies have highlighted the biological properties of VOO phenolic compounds elucidating their anti-inflammatory activities. This paper will review current knowledge on the anti-inflammatory and nutrigenomic, chemoprotective and anti-atherosclerotic activities of VOO phenolics. In addition the concentration, metabolism and bioavailability of specific phenolic compounds will be discussed. The evidence presented in the review concludes that oleurepein, hydroxytyrosol and oleocanthal have potent pharmacological activities in vitro and in vivo; however, intervention studies with biologically relevant concentrations of these phenolic compounds are required.
\end{abstract}

Keywords: olive oil phenolics; olive oil; health benefits; inflammation

\section{Introduction}

The health promoting attributes associated with following a traditional Mediterranean diet have been reviewed extensively. The first suggestion of healthful effects arose from the Seven Countries Study conducted in the 1970's [1]. It has since been confirmed that the prevalence of chronic inflammatory disease for Mediterranean populations is the lowest in the world, and life expectancy amongst the highest [2]. As a result, nutrition research has focused on populations residing along the Mediterranean Sea to uncover key nutrients and dietary patterns that may be associated with reported superior health status. Since the early Seven Countries Study, several other studies have supported the view that this pattern of eating is associated with a reduced incidence of inflammatory disease states [3-17]. This review discusses the modes of action through which VOO phenolic compounds may exert their health protective effects, together with information on the concentrations in which they are found in VOO, their degree of bioavailability and metabolism. A search for relevant literature published in English was conducted via PubMed. Relevant research articles were identified using the following key words: olive oil phenolics, hydroxytyrosol, oleuropein, oleocanthal and health benefits, inflammation, inflammatory disease, cancer, obesity, Alzheimer's disease, bioavailability. The reference lists of included articles and recent significant reviews were also examined to identify relevant publications. 


\section{Virgin Olive Oil}

The principle source of dietary fat in the Mediterranean diet is VOO $[18,19]$ and VOO contributes significantly to the superior health profile observed in Mediterranean populations [20,21]. In fact, throughout history, $\mathrm{VOO}$ has been recognized as being a potent pharmacological agent by ancient Greek doctors, and Hippocrates mentions approximately 60 health conditions where VOO use can be beneficial [22]. A large body of evidence has highlighted the benefits of VOO intake on primary end points for cardiovascular disease (CVD) and total mortality as well as secondary risk factors for chronic inflammatory diseases such as cancer, endothelial function and hypertension [23].

\section{Phenolic Fraction}

It is now known that $\mathrm{VOO}$ contains approximately 36 phenolic compounds and these compounds play a key role in the health promoting qualities of the oil [7,23-26]. Research investigating VOO phenolics and benefits to human health has focused on inflammation, antioxidant status, antimicrobial activity, as well as other biological markers of non-communicable disease (for an earlier review see [25]). The principle phenolics of interest in this review are secoiridoid oleuropein, and its derivative hydroxytyrosol, and the minor phenolic compound oleocanthal.

\section{Virgin Olive Oil Phenolic Concentration}

Over $30 \mathrm{VOO}$ phenolic compounds have been identified and considerable variation has been noted in the concentration of such phenolic compounds $(0.02$ to $600 \mathrm{mg} / \mathrm{kg})$ [24]. VOO phenolic compounds can be grouped into the following: phenolic acids, phenolic alcohols, secoiridoids, hydroxy-isocromans, flavonoids and lignans. Phenolic acids are present in the smallest of quantities in VOO. Conversely, secoiridoids are present in the largest of quantities in VOO. Phenolic alcohols, flavonoids and lignans are present in quantities between those of phenolic acids and secoiridoids. Quantity data for hydroxy-isocromans are currently limited.

A number of factors have been shown to affect the concentration of phenolic compounds in VOO and these include olive fruit cultivar and variety, region of growth, agricultural cultivation techniques, maturity at harvest, processing, and storage. Also, olive tree age has been shown to influence phenolic content [24].

\section{Virgin Olive Oil Bioavailability and Metabolism}

The phenolic concentration and composition of VOO together with the degree to which these components are absorbed and metabolized are essential in determining the health effects associated with such compounds. Bioavailability of VOO phenolic compounds is the key in achieving an effect in specific tissues or organs [27].

The majority of research regarding the bioavailability of these compounds has focused on the two most abundant VOO phenolics: hydroxytyrosol and tyrosol, amongst a few others [28]. Research evidence demonstrates that there is significant absorption $(\sim 40 \%-95 \%)$ of these compounds in a dose-dependent manner in humans [29-33]. Moreover, Tuck et al. [32] noted the increase in bioavailability of hydroxytyrosol and tyrosol when administered as an olive oil solution compared to an aqueous solution. This finding suggests the $\mathrm{VOO}$ itself may have acted as a protective factor preventing the breakdown of the phenolics in the gastrointestinal tract prior to absorption [32]. Vissers and colleagues [31] found that absorption of administered ligstroside-aglycone, hydroxytyrosol, tyrosol, and oleuropein-aglycone was $55 \%-66 \%$ in human subjects. A much smaller quantity of these phenolics was recovered in urine (5\%-16\%). Furthermore, Miro Casas and colleagues [33] demonstrated a mean urinary recovery of $25 \%$ of administered tyrosol. Visioli et al. [34] also reported urinary excretion of administered hydroxytyrosol as $30 \%-60 \%$ and $20 \%-22 \%$ for tyrosol. These figures indicate that humans absorb a major part of VOO phenolics ingested. 
With regards to the metabolism of VOO phenolics, the presence of metabolites from the majority of olive oil phenolic compounds (i.e., secoiridoids, flavanoids and phenolic alcohols) in human urine has been noted [35]. This implies that such compounds are metabolized and absorbed post-ingestion. Varying rates of metabolism amongst differing VOO phenolics have also been found. The largest number of metabolites produced post-ingestion have been found with hydroxytyrosol, oleuropein aglycone and oleocanthal, with circulating metabolites ranging from 10-60 $\mu$ g post-ingestion of a $50 \mathrm{~mL}$ high phenol-containing VOO. By contrast, the lowest number of metabolites have been found with tyrosol, luteolin, apigenin, pinoresinol and acetoxypinoresinol (concentration not stated in study) [35]. In the case of poorly absorbed VOO phenolics, it has been postulated that these compounds may exert local antioxidant activities in the gastrointestinal tract and this proposal is supported by research demonstrating the free radical scavenging capacity of VOO phenolics in both the fecal matrix and intestinal epithelial cells [36]. Further, it is has been suggested that unabsorbed VOO phenolics may exert antimicrobial activities in the gastrointestinal tract [37].

VOO intake for Mediterranean populations is reported to be 30-50 g/day [38]. If we assume this quantity of VOO contains $200 \mu \mathrm{g}$ phenolics and the absorption rate is in the range of $40 \%-95 \%$ of the ingested olive oil phenols, it may be assumed that the quantity of ingested olive oil phenols are in the range of 4-9 mg/day. While the in vivo studies discussed in this review suggest physiologically relevant concentrations, many in vivo studies use supraphysiological concentrations $(>10 \mu \mathrm{M})[39]$. Therefore, it is difficult to translate this into physiological relevance, and future research is needed using concentrations that can be extrapolated to humans. Also of consideration is that VOO phenolics are consumed in a diet and possibly interact with other compounds within the food matrix. Therefore, it is important to consider such factors when investigating the health benefits of such components in humans.

\section{Virgin Olive Oil Phenolics as Anti-Inflammatory and Nutraceutical Agents}

It is known that the pathophysiology of common disease states such as cancer, CVD, arthritis and neurodegenerative disease takes root in chronic inflammation [40]. Phenolic compounds derived from VOO have been reported to possess significant anti-inflammatory qualities. It has been reported that postprandial inflammatory response after ingestion of heated vegetable oils in obese individuals is significantly reduced by phenolic-rich VOO [41]. Although the effect of monounsaturated fatty acids in VOO may be similar as that of the phenolic component, the authors report that VOO or a mix of sunflower and rapeseed oil artificially enriched with olive oil phenolic compounds and other antioxidants mitigate postprandial inflammation. The phenolic enriched oil reduces nuclear factor kappa-light-chain-enhancer of activated B cells (NF-kB) activation, increases nuclear factor of kappa light polypeptide gene enhancer in B-cells inhibitor, alpha (IkB-a), and decreases lipopolysaccharide (LPS) plasma concentration, compared with sunflower oil, demonstrating the potent effects that VOO phenolics have on inflammatory markers.

There are now several studies that have examined the anti-inflammatory and cardio-protective effects of olive oil phenolic compounds in humans. These studies suggest that VOO with high phenolic concentration is effective in modulating inflammatory mediators derived from arachidonic acid, such as thromboxane B2 and 6-keto-PG F1a, as well as other inflammatory markers, such as high-sensitivity C-reactive protein (CRP) and interleukin 6 (IL-6) [42-44]. More recently, Muto and colleagues [45] investigated the effects of olive oil phenolics on Caco-2 cells exposed to the inflammatory effects of LPS. They report that an olive oil phenolic extract attenuates interleukin 8 (IL-8) expression and that the phenolic fraction can modulate an acute inflammatory response in intestinal epithelial cells. Table 1 lists the in vitro and in vivo studies demonstrating the effect of oleocanthal, oleuropein, and hydroxytyrosol on markers of disease.

In regard to the specific actions of the phenolic oleuropein, early evidence demonstrates this phenolic inhibits tumour necrosis factor alpha (TNFa) induced matrix metalloproteinase 9 (MMP-9) in a monocyte cell line. This has implications for health as monocytes, and the molecules they secrete 
play a significant role in inflammatory disease development [46]. Further, the administration of oleuropein $30 \mathrm{~min}$ after challenge with TNFa produced a significant reduction in cytokine induced matrix metalloproteinases (MMPs), which amplify the inflammatory response and also contribute to atherosclerotic changes in arterial walls [46].

Furthermore, the phenolic compound oleocanthal has been found to share the same mechanistic anti-inflammatory pathway as the non-steroidal anti-inflammatory drug, ibuprofen. In vitro, oleocanthal has been shown to inhibit both cyclooxygenase-1 (COX-1) and cyclooxygenase-2 (COX-2) inflammatory enzymes in a dose-dependent manner, and is more effective than ibuprofen in inhibiting these enzymes at equimolar concentrations [47]. The anti-inflammatory actions of oleocanthal extend to pharmacological actions in attenuating inflammatory mediators such as inducible nitric oxide synthase (iNOS) which plays a role in the pathogenesis of joint degenerative disease [48,49].

Further evidence suggests that oleocanthal may be a potent pharmacological agent in the treatment of neurogenerative disease, as this compound exhibits neuroprotective properties, in addition to attenuating markers of inflammation implicated in Alzheimer's disease [50-53]. However, it must be considered that results from in vitro models may not extend to in vivo models of disease due to the inability of some compounds to cross the blood-brain barrier. Abuznait and colleagues (2015) report that expression of P-glycoprotein (P-gp) and LDL lipoprotein receptor related protein-1 (LRP1) in the brain microvessels of C57BL/ 6 mice is increased after oleocanthal treatment These transport proteins are responsible for the clearance of $\beta$-amyloid $(A \beta)$ across the blood-brain barrier and $A \beta$ is a hallmark in the risk of Alzheimer's disease. Therefore, it would seem that oleocanthal induces P-gp and LRP1 and enhances $A \beta$ clearance across the blood brain barrier $[53,54]$.

Hydroxytyrosol has been reported to possess significant anti-inflammatory actions in an animal model of inflammation and to attenuate TNFa and interleukin $1 \beta$ (IL-1b) expression, which are pro-inflammatory cytokines often observed in inflammatory disease [55] Furthermore, in vitro evidence shows the attenuation of pro-inflammatory agents iNOS, COX-2 and TNFa by hydroxytyrosol in LPS-challenged human monocytic THP-1 cells [56].

Table 1. In vitro and in vivo studies demonstrating the effect of oleocanthal, oleuropein, and hydroxytyrosol on markers of disease.

\begin{tabular}{|c|c|c|c|c|}
\hline $\begin{array}{l}\text { Olive Oil Phenolic } \\
\text { Treatment } \\
\text { Concentration }\end{array}$ & $\begin{array}{l}\text { Health/Disease } \\
\text { Outcome }\end{array}$ & In Vitro/In Vivo Model & Key Findings & Reference \\
\hline $\begin{array}{l}\text { Oleocanthal } \\
(1-25 \mu \mathrm{M})\end{array}$ & $\begin{array}{l}\text { Joint degenerative } \\
\text { disease }\end{array}$ & $\begin{array}{l}\text { Murine chondrocytes. } \\
\text { In vitro }\end{array}$ & $\begin{array}{l}\text { Oleocanthal and its derivative } 231 \\
\text { down-regulate iNOS protein expression } \\
\text { in LPS-challenged chondrocytes reducing } \\
\text { nitrate levels. }\end{array}$ & $\begin{array}{l}\text { Iacono et al. } \\
\text { (2010) [48] }\end{array}$ \\
\hline $\begin{array}{l}\text { Oleocanthal } \\
(50 \mu \mathrm{M})\end{array}$ & $\begin{array}{l}\text { Joint degenerative } \\
\text { disease }\end{array}$ & $\begin{array}{l}\text { Murine chondrocytes, } \\
\text { Murine macrophages } \\
\text { In vitro }\end{array}$ & $\begin{array}{l}\text { Oleocanthal attenuates IL- } 6 \text { and MIP- } \\
\text { in vitro. The anti-inflammatory actions of } \\
\text { oleocanthal in macrophages are related to } \\
\text { the inhibition of NO production, via } \\
\text { iNOS down regulation, and also to the } \\
\text { decrease of relevant } \\
\text { pro-inflammatory cytokines. }\end{array}$ & $\begin{array}{l}\text { Scotece et al. } \\
\text { (2013) [49] }\end{array}$ \\
\hline $\begin{array}{l}\text { Oleocanthal } \\
(10 \mathrm{nM})\end{array}$ & $\begin{array}{l}\text { Neurodegenerative } \\
\text { disease }\end{array}$ & $\begin{array}{l}\text { Primary hippocampal } \\
\text { cultures } \\
\text { In vitro }\end{array}$ & $\begin{array}{l}\text { Oleocanthal alters the oligomerization } \\
\text { state of ADDLs while protecting neurons } \\
\text { from the synaptopathological effects } \\
\text { of ADDLs. }\end{array}$ & $\begin{array}{l}\text { Pitt et al. } \\
\text { (2009) [50] }\end{array}$ \\
\hline $\begin{array}{l}\text { Oleocanthal } \\
(100 \mu \mathrm{M})\end{array}$ & $\begin{array}{l}\text { Neurodegenerative } \\
\text { disease }\end{array}$ & $\begin{array}{l}\text { Tau fibrils } \\
\text { In vitro }\end{array}$ & $\begin{array}{l}\text { Oleocanthal inhibits tau fibrillization } \\
\text { which is a risk factor for } \\
\text { Alzheimer's disease }\end{array}$ & $\begin{array}{l}\text { Monti et al. } \\
\text { (2011) [51] }\end{array}$ \\
\hline $\begin{array}{l}\text { Oleocanthal } \\
(100 \mu \mathrm{M})\end{array}$ & $\begin{array}{l}\text { Neurodegenerative } \\
\text { disease }\end{array}$ & $\begin{array}{l}\text { Tau Fibrils } \\
\text { In vitro }\end{array}$ & $\begin{array}{l}\text { Oleocanthal prevents fibrillization of tau } \\
\text { by locking tau into the naturally } \\
\text { unfolded state. }\end{array}$ & $\begin{array}{l}\text { Li et al. } \\
\text { (2009) [52] }\end{array}$ \\
\hline $\begin{array}{l}\text { Hydroxytyrosol } \\
\qquad(1-10 \mu \mathrm{M})\end{array}$ & $\begin{array}{l}\text { Anti-inflammatory and } \\
\text { anti-atherosclerotic } \\
\text { activity }\end{array}$ & $\begin{array}{l}\text { Human monocytic } \\
\text { THP-1 cells } \\
\text { In vitro }\end{array}$ & $\begin{array}{l}\text { Hydroxytyrosol blunts MMP-9 release } \\
\text { and reduces COX-2 and NF- } \mathrm{kB} \text { activation, } \\
\text { suggesting a vascular protective effect. }\end{array}$ & $\begin{array}{l}\text { Scoditti et al. } \\
\text { (2014) [57] }\end{array}$ \\
\hline
\end{tabular}


Table 1. Cont

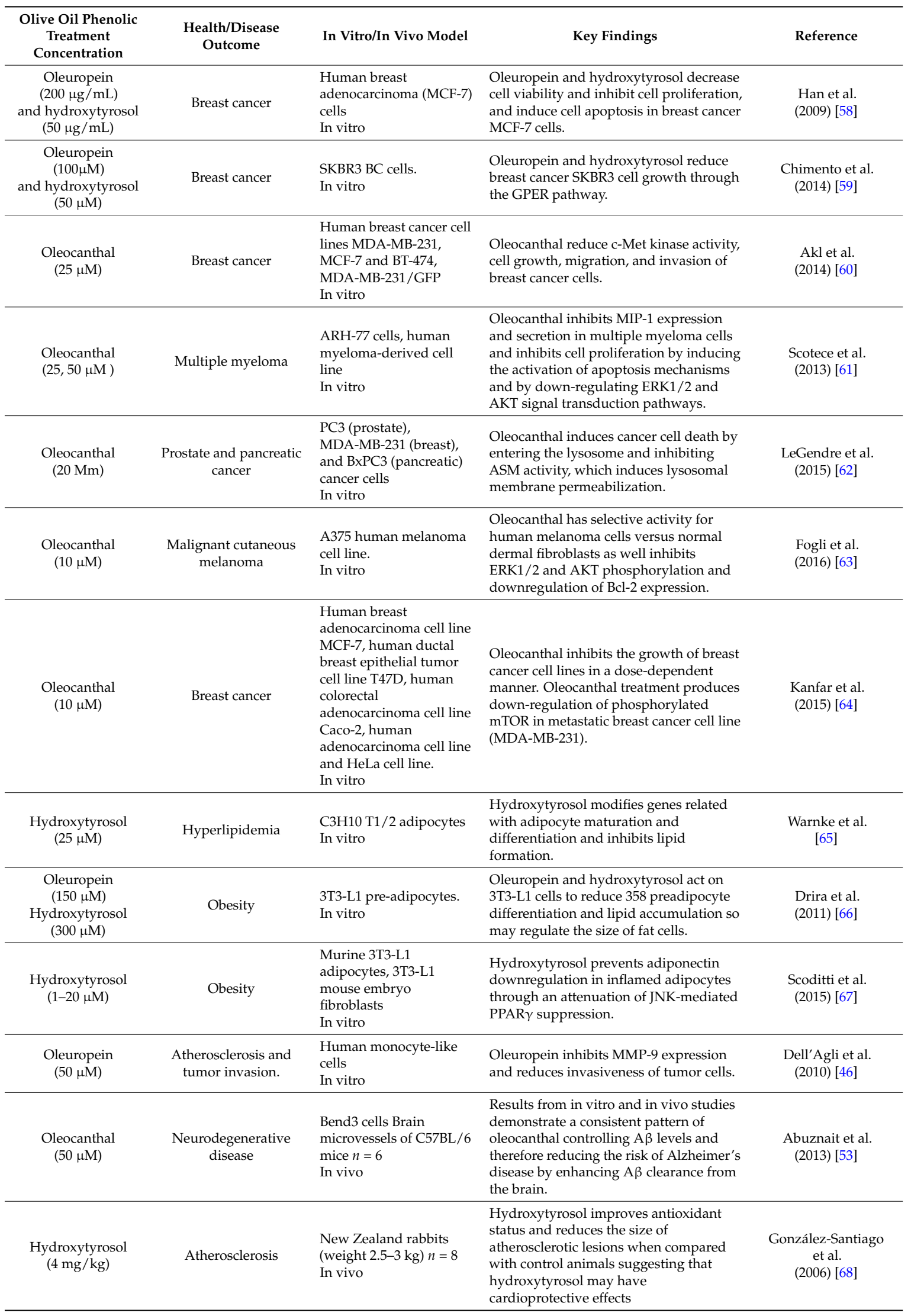


Table 1. Cont.

\begin{tabular}{|c|c|c|c|c|}
\hline $\begin{array}{l}\text { Olive Oil Phenolic } \\
\text { Treatment } \\
\text { Concentration }\end{array}$ & $\begin{array}{l}\text { Health/Disease } \\
\text { Outcome }\end{array}$ & In Vitro/In Vivo Model & Key Findings & Reference \\
\hline $\begin{array}{c}\text { Oleocanthal } \\
(30 \mu \mathrm{M}) \\
\text { in vitro in vivo } \\
5 \mathrm{mg} / \mathrm{kg} / \mathrm{d} \text { or } \\
10 \mathrm{mg} / \mathrm{kg} / \mathrm{d} \\
\text { for eight weeks }\end{array}$ & $\begin{array}{l}\text { Hepatocellular } \\
\text { carcinoma }\end{array}$ & $\begin{array}{l}\text { HCC cell lines (Huh-7, } \\
\text { HepG2 and HCCLM3 } \\
\text { BALB/c mice } n=6 \\
\text { In vivo }\end{array}$ & $\begin{array}{l}\text { Oleocanthal inhibits hepatocellular } \\
\text { carcinoma tumor growth and metastasis } \\
\text { by inactivating STAT3 both in vitro and } \\
\text { in vivo. }\end{array}$ & $\begin{array}{l}\text { Pei et al. } \\
\text { (2016) [69] }\end{array}$ \\
\hline $\begin{array}{c}\text { Oleuropein } \\
(125 \mathrm{mg} / \mathrm{kg} \text { of diet })\end{array}$ & Lung metastases & $\begin{array}{l}\text { MCF-7 cells xenograft } \\
\text { growth in } \\
\text { ovariectomised mice } \\
n=20 \\
\text { In vivo }\end{array}$ & $\begin{array}{l}\text { Oleuropein prevents both peripulmonary } \\
\text { and parenchyma lung metastases. }\end{array}$ & $\begin{array}{l}\text { Sepporta et al. } \\
\text { (2014) [70] }\end{array}$ \\
\hline $\begin{array}{c}\text { Hydroxytyrosol } \\
(100,250,500 \mathrm{mg} / \mathrm{kg})\end{array}$ & $\begin{array}{l}\text { Inflammatory swelling } \\
\text { and hyperalgesia }\end{array}$ & $\begin{array}{l}\text { Male Sprague-Dawley } \\
\text { rats } n=50 . \\
\text { In vivo }\end{array}$ & $\begin{array}{l}\text { Hydroxytyrosol decreases } \\
\text { pro-inflammatory cytokines IL- } 1 \beta \text { and } \\
\text { TNF- } \alpha \text {, reducing paw inflammation. }\end{array}$ & $\begin{array}{l}\text { Gong et al. } \\
(2009)[55]\end{array}$ \\
\hline
\end{tabular}

\section{Virgin Olive Oil Phenolics and Cancer}

Due to the anti-inflammatory efficacy of VOO phenolics, much research has focused on the pharmacological properties of these compounds, in particular the anti-carcinogenic actions. There is much research suggesting that oleuropein and its metabolite, hydroxytyrosol, exert anti-cancer properties. An early study has shown that high doses of oleuropein at a concentration of $200 \mu \mathrm{g} / \mathrm{mL}$ decreased cell viability and inhibited cell proliferation in human breast adenocarcinoma (MCF-7) breast cancer cells [58]. Furthermore, a study using oleuropein as the dominant compound from crude extracts derived from the olive leaf inhibited cell proliferation of MCF-7, human urinary bladder carcinoma and bovine brain capillary endothelial [71]. Of importance is an in vivo study [70] that showed oleuropein possesses anti-cancer activity and inhibited both MCF-7 cell growth and their invasiveness into the lung. This study demonstrates that oleuropein prevents both peripulmonary and parenchyma lung metastases in vivo [70].

Chimento and colleagues [59] report that micromolar concentrations of oleupopein and hydroxytyrosol reduce SKBR3 cell growth by exhibiting sustained ERK1/2 activation, triggering an intrinsic apoptotic pathway. The VOO phenolic oleocanthal has also been shown to possess anti-proliferative effects in human breast, prostate, and bone cancer lines [60,61]. Recently, LeGendre and colleagues [62] reported that oleocanthal promoted primary necrotic cell death in serum-starved cancer cells. This was associated with elevated levels of phosphorylated ERK1/2 in the absence of cleaved caspase-3 expression. In serum, the cancer cells exhibited both apoptosis and secondary necrosis. Additionally, oleocanthal has been shown to inhibit proliferation and induced apoptosis in hepatocellular carcinoma (HCC) cells in vitro [69]. It was reported that the oleocanthal treated group of mice had fewer and smaller lung metastases compared to the control group [69]. The study concluded that oleocanthal inhibits HCC tumor growth and metastasis by inactivating STAT3 both in vitro and in vivo. STAT3 is a transcription factor and is implicated in the survival, proliferation, invasion, and angiogenesis of HCC by regulating the expression of target genes. Therefore, STAT3 may be a promising target for HCC therapy [69]. A recent study has also shown that oleocanthal inhibits extracellular signal-regulated kinases 1/2 (ERK1/2) and AKT phosphorylation as well as down-regulates Bcl-2 expression. AKT, ERK1/2 and are necessary, not only for c-Met-mediated regulation of cell motility, adhesion, and invasion, but also for control of cell survival and mitogenesis [72] and through this, induces cytotoxicity against human melanoma cells [63].

A recent study showed that oleocanthal inhibits the mammalian target of rapamycin (mTOR) [64]. mTOR is a serine/threonine kinase and member of the PI3K-related kinase family. It has a crucial role in integrating signals from energy homeostasis, metabolism, stress response, and the cell cycle, and dysregulated PI3K/mTOR signaling is frequently observed in cancers [73]. Oleocanthal treatment $(10 \mu \mathrm{M})$ caused a marked downregulation of the phosphorylated mTOR (p-mTOR) in a metastatic 
breast cancer cell line (MDA-MB-231), suggesting that the anti-carcinogenic activity of oleocanthal is potentially mediated by mTOR inhibition [64].

\section{Virgin Olive Oil Phenolics and Atherosclerosis}

Early research has shown that VOO phenolics improve endothelial dysfunction and reduce oxidative stress plasma parameters [74,75], which play a key role in the development of atherosclerosis. In support of the beneficial effects VOO phenolics exert on atherosclerosis risk factors, Konstantinidou and colleagues [76] reported that VOO containing $328 \mathrm{mg} / \mathrm{kg}$ compared to $55 \mathrm{mg} / \mathrm{kg}$ of phenolics down-regulates inflammatory genes Rho-GTPase-activating protein 15, interferon gamma and interleukin 7 receptor and also adrenergic beta 2 receptor and polymerase kappa; these are all implicated in atherosclerosis. Using a rabbit animal model, Gonzalez and colleagues [68] reported that in the presence of saturated fat and cholesterol, hydroxytyrosol at $4 \mathrm{mg} / \mathrm{kg}$ reduced the size of atherosclerotic lesions when compared with rabbits receiving this diet without hydroxytyrosol [68].

Furthermore, a recent randomized control trial reported that VOO phenolic intake decreased low density lipoprotein (LDL) concentrations and LDL atherogenicity in vivo [77]. This study involved the intake of $25 \mathrm{~mL} /$ day of raw high-polyphenol content olive oil (366 mg/ $\mathrm{kg}$ ) or low-polyphenol-content olive oil $(2.7 \mathrm{mg} / \mathrm{kg})$ for 3 weeks. VOO phenolics decreased LDL concentrations directly measured as concentrations of apo B-100 and the total number of LDL particles. Additionally, conclusions were drawn that VOO phenolics decrease LDL atherogenicity, which was reflected in the lower number of small LDL particles and enhanced LDL resistance to oxidation [77]. These studies add to previous evidence that $\mathrm{VOO}$ phenolics improve oxidative status and reduce cardiovascular risk factors $[75,78,79]$.

\section{Virgin Olive Oil Phenolics and Obesity}

VOO phenolics have been shown to influence the expression of genes related to obesity. Warnke and colleagues observed that hydroxytyrosol at a concentration of $25 \mu \mathrm{M}$ was able to modify genes related to adipocyte maturation and differentiation and to have an inhibitory effect on lipid formation [65]. Hyperlipidemia is detrimental to coronary arteries and the most important risk factor for heart disease. Additionally, Drira and colleagues reported that both hydroxytyrosol and oleuropein at concentrations of 100 and $150 \mu \mathrm{M}$ and 200 and $300 \mu \mathrm{M}$ respectively, inhibit adipocyte differentiation by downregulation of adipogenesis-related genes PPAR $\gamma, \mathrm{C} / \mathrm{EBP} \alpha$ and SREBP-1c transcription factors and downstream genes (GLUT4, CD36 and FASN) meaning that VOO phenolics may reduce the size of fat cells and be of benefit in reducing the risk of obesity [66].

In an animal model of high fat diet-induced obesity, hyperglycemia, hyperlipidemia, and insulin resistance, it was shown that hydroxytyrosol decreased high fat diet-induced lipid deposits. The mechanism of action was the inhibition of the SREBP-1c/FAS pathway in liver and skeletal muscle tissues, an increase in antioxidant enzyme activities, and the normalization of the expression of mitochondrial complex subunits and mitochondrial fission marker Drp1 [80]. Further, Scoditti and colleagues [67] reported that hydroxytyrosol, at nutritionally relevant concentrations, exert significant actions, including adiponectin downregulation in inflamed adipocytes through attenuation of JNK-mediated PPAR $\gamma$ suppression [67]. Hydroxytyrosol was effective at concentrations as low as $1 \mu \mathrm{mol} / \mathrm{L}$. This is in the range of plasma concentrations of hydroxytyrosol $(0.01$ to $10 \mu \mathrm{mol} / \mathrm{L})$ that have been reported after dietary consumption of VOO [81], implying that the actions of hydroxytyrosol are relevant at physiological concentrations.

These data indicate that VOO phenolics may have a protective role against excessive fat accumulation associated with systemic oxidative stress as well as exert beneficial effects against the development of metabolic syndrome. However, clinical studies are needed to support the evidence from in vitro and animal models. 


\section{Conclusions}

To conclude, the beneficial effects of VOO phenolics on health have been researched extensively, and recent research supports earlier evidence that these components exert beneficial effects on physiological processes related to health and disease. A number of studies both in vivo and in vitro demonstrate that $\mathrm{VOO}$ phenolic compounds beneficially alter inflammation and have beneficial effects on markers of cancer, atherosclerosis and also genes related to obesity and metabolic syndrome. The modes of action through which olive oil phenolic compounds beneficially influence health parameters detailed in this review may explain the lower incidence of chronic inflammatory diseases amongst populations residing in the Mediterranean region, who consume large volumes of VOO in their daily diets. The evidence presented in the review concludes that oleuropein, hydroxytyrosol and oleocanthal possess potent pharmacological activities in vitro and in vivo. This expanding collection of evidence would further benefit from human intervention studies with biologically relevant concentrations of these phenolic compounds.

Conflicts of Interest: The authors declare no conflict of interest.

\section{References}

1. Keys, A. Coronary heart disease in seven countries. Circulation 1970, 41, 186-195. [CrossRef]

2. World Health Organization (WHO). World Health Statistics 2010; World Health Organization: Geneva, Switzerland, 2010.

3. Michel de Lorgeril, M.; Salen, P.; Martin, J.-L.; Monjaud, I.; Delaye, J.; Mamelle, N. Mediterranean diet, traditional risk factors, and the rate of cardiovascular complications after myocardial infarction. Circulation 1999, 99, 779-785. [CrossRef]

4. Singh, R.B.; Dubnov, G.; Niaz, M.A.; Ghosh, S.; Singh, R.; Rastogi, S.S.; Manor, O.; Pella, D.; Berry, E.M. Effect of an Indo-Mediterranean diet on progression of coronary artery disease in high risk patients (Indo-Mediterranean Diet Heart Study): A randomised single-blind trial. Lancet 2002, 360, 1455-1461. [CrossRef]

5. Stark, A.H.; Madar, P.Z. Olive oil as a functional food: Epidemiology and nutritional approaches. Nutr. Rev. 2002, 60, 170-176. [CrossRef] [PubMed]

6. Grosso, G.; Pajak, A.; Mistretta, A.; Marventano, S.; Raciti, T.; Buscemi, S.; Drago, F.; Scalfi, L.; Galvano, F. Protective role of the Mediterranean diet on several cardiovascular risk factors: Evidence from Sicily, southern Italy. Nutr. Metab. Cardiovasc. Dis. 2013, 24, 370-377. [CrossRef] [PubMed]

7. Estruch, R.; Ros, E.; Salas-Salvadó, J.; Covas, M.-I.; Corella, D.; Arós, F.; Gómez-Gracia, E.; Ruiz-Gutiérrez, V.; Fiol, M.; Lapetra, J.; et al. Primary Prevention of Cardiovascular Disease with a Mediterranean Diet. N. Engl. J. Med. 2013, 368, 1279-1290. [CrossRef] [PubMed]

8. Sexton, P.; Black, P.; Metcalf, P.; Wall, C.R.; Ley, S.; Wu, L.; Sommerville, F.; Brodie, S.; Kolbe, J. Influence of Mediterranean Diet on Asthma Symptoms, Lung Function, and Systemic Inflammation: A Randomized Controlled Trial. J. Asthma 2013, 50, 75-81. [CrossRef] [PubMed]

9. Mitrou, P.N.; Kipnis, V.; Thiébaut, A.C.; Reedy, J.; Subar, A.F.; Wirfält, E.; Flood, A.; Mouw, T.; Hollenbeck, A.R.; Leitzmann, M.F. Mediterranean dietary pattern and prediction of all-cause mortality in a US population: Results from the NIH-AARP Diet and Health Study. Arch. Intern. Med. 2007, 167, 2461-2468. [CrossRef] [PubMed]

10. Martínez-González, M.A.; García-López, M.; Bes-Rastrollo, M.; Toledo, E.; Martínez-Lapiscina, E.H.; Delgado-Rodriguez, M.; Vazquez, Z.; Benito, S.; Beunza, J.J. Mediterranean diet and the incidence of cardiovascular disease: A Spanish cohort. Nutr. Metab. Cardiovasc. Dis. 2011, 21, 237-244. [CrossRef] [PubMed]

11. Carter, S.J.; Roberts, M.B.; Salter, J.; Eaton, C.B. Relationship between Mediterranean diet score and atherothrombotic risk: Findings from the Third National Health and Nutrition Examination Survey (NHANES III), 1988-1994. Atherosclerosis 2010, 210, 630-636. [CrossRef] [PubMed]

12. Shen, J.; Wilmot, K.A.; Ghasemzadeh, N.; Molloy, D.L.; Burkman, G.; Mekonnen, G.; Gongora, M.C.; Quyyumi, A.A.; Sperling, L.S. Mediterranean Dietary Patterns and Cardiovascular Health. Annu. Rev. Nutr. 2015, 35, 425-449. [CrossRef] [PubMed] 
13. Whalen, K.; McCullough, M.; Flanders, W.D.; Hartman, T.J.; Judd, S.; Bostick, R.M. Paleolithic and Mediterranean diet pattern scores and their associations with biomarkers of inflammation and oxidative balance. Cancer Res. 2015, 75 (Suppl. S15), 1889. [CrossRef]

14. Berrino, F. Mediterranean Diet and Its Association With Reduced Invasive Breast Cancer Risk. JAMA Oncol. 2016, 2, 535-536. [CrossRef] [PubMed]

15. Turati, F.; Pelucchi, C.; Galeone, C.; Praud, D.; Tavani, A.; La Vecchia, C. Mediterranean diet and non-fatal acute myocardial infarction: A case-control study from Italy. Public Health Nutr. 2015, 18, 713-720. [CrossRef] [PubMed]

16. Toledo, E.; Salas-Salvadó, J.; Donat-Vargas, C.; Buil-Cosiales, P.; Estruch, R.; Ros, E.; Corella, D.; Fitó, M.; Hu, F.B.; Arós, F. Mediterranean diet and invasive breast cancer risk among women at high cardiovascular risk in the PREDIMED trial: A randomized clinical trial. JAMA Intern. Med. 2015, 175, 1752-1760. [CrossRef] [PubMed]

17. Hoffmann, G.; Schwingshackl, L. Mediterranean diet supplemented with extra virgin olive oil reduces the incidence of invasive breast cancer in a randomised controlled trial. Evid. Based Med. 2016, 21, 72. [CrossRef] [PubMed]

18. Bach-Faig, A.; Berry, E.M.; Lairon, D.; Reguant, J.; Trichopoulou, A.; Dernini, S.; Medina, F.X.; Battino, M.; Belahsen, R.; Miranda, G. Mediterranean diet pyramid today. Science and cultural updates. Public Health Nutri. 2011, 14, 2274-2284. [CrossRef] [PubMed]

19. Sahyoun, N.R.; Sankavaram, K. Historical origins of the Mediterranean Diet, Regional Dietary Profiles, and the Development of the Dietary Guidelines. In Mediterranean Diet; Springer: Cham, Switzerland, 2016; pp. $43-56$.

20. Tripoli, E.; Giammanco, M.; Tabacchi, G.; Di Majo, D.; Giammanco, S.; La Guardia, M. The phenolic compounds of olive oil: Structure, biological activity and beneficial effects on human health. Nutr. Res. Rev. 2005, 18, 98-112. [CrossRef] [PubMed]

21. Serra-Majem, L.; Trichopoulou, A. Trichopoulou, Updating the Benefits of the Mediterranean Diet: From the Heart to the Earth. In Mediterranean Diet; Springer: Cham, Switzerland, 2016; pp. 3-14.

22. Caramia, G.; Gori, A.; Valli, E.; Cerretani, L. Virgin olive oil in preventive medicine: From legend to epigenetics. Eur. J. Lipid Sci. Technol. 2012, 114, 375-388. [CrossRef]

23. Covas, M.-I.; Fitó, M.; de la Torre, R. Minor Bioactive Olive Oil Components and Health: Key Data for Their Role in Providing Health Benefits in Humans. In Olive and Olive Oil Bioactive Constituents; Elsevier, Inc.: Philadelphia, PA, USA, 2015; p. 31.

24. Cicerale, S.; Conlan, X.A.; Sinclair, A.J.; Keast, R.S.J. Chemistry and health of olive oil phenolics. Crit. Rev. Food Sci. Nutr. 2009, 49, 218-236. [CrossRef] [PubMed]

25. Cicerale, S.; Lucas, L.; Keast, R. Antimicrobial, antioxidant and anti-inflammatory phenolic activities in extra virgin olive oil. Curr. Opin. Biotechnol. 2012, 23, 129-135. [CrossRef] [PubMed]

26. Bernardini, E.; Visioli, F. High quality, good health: The case for olive oil. Eur. J. Lipid Sci. Technol. 2016. [CrossRef]

27. Soler, A.; Romero, M.P.; Macià, A.; Saha, S.; Furniss, C.S.; Kroon, P.A.; Motilva, M.J. Digestion stability and evaluation of the metabolism and transport of olive oil phenols in the human small-intestinal epithelial Caco-2/TC7 cell line. Food Chem. 2010, 119, 703-714. [CrossRef]

28. Rodríguez-Morató, J.; Boronat, A.; Kotronoulas, A.; Pujadas, M.; Pastor, A.; Olesti, E.; Pérez-Mañá, C.; Khymenets, O.; Fitó, M.; Farré, M. Metabolic disposition and biological significance of simple phenols of dietary origin: Hydroxytyrosol and tyrosol. Drug Metab. Rev. 2016, 48, 218-236. [CrossRef] [PubMed]

29. Visioli, F.; Galli, C.; Bornet, F.; Mattei, A.; Patelli, R.; Galli, G.; Caruso, D. Olive oil phenolics are dose-dependently absorbed in humans. FEBS Lett. 2000, 468, 159-160. [CrossRef]

30. Visioli, F.; Caruso, D.; Plasmati, E.; Patelli, R.; Mulinacci, N.; Romani, A.; Galli, G.; Galli, C. Hydroxytyrosol, as a component of olive mill waste water, is dose-dependently absorbed and increases the antioxidant capacity of rat plasma. Free Radic. Res. 2001, 34, 301-305. [CrossRef] [PubMed]

31. Vissers, M.N.; Zock, P.L.; Roodenburg, A.J.; Leenen, R.; Katan, M.B. Olive oil phenols are absorbed in humans. J. Nutr. 2002, 132, 409-417. [PubMed]

32. Tuck, K.L.; Hayball, P.J. Major phenolic compounds in olive oil: Metabolism and health effects. J. Nutr. Biochem. 2002, 13, 636-644. [CrossRef] 
33. Casas, E.M.; Albadalejo, M.F.; Planells, M.I.C.; Colomer, M.F.; Raventós, R.M.L.; de la Torre Fornell, R. Tyrosol bioavailability in humans after ingestion of virgin olive oil. Clin. Chem. 2001, 47, 341-343.

34. Visioli, F.; Galli, C.; Plasmati, E.; Viappiani, S.; Hernandez, A.; Colombo, C.; Sala, A. Olive phenol hydroxytyrosol prevents passive smoking-induced oxidative stress. Circulation 2000, 102, 2169-2171. [CrossRef] [PubMed]

35. García-Villalba, R.; Carrasco-Pancorbo, A.; Nevedomskaya, E.; Mayboroda, O.A.; Deelder, A.M.; Segura-Carretero, A.; Fernández-Gutiérrez, A. Exploratory analysis of human urine by LC-ESI-TOF MS after high intake of olive oil: Understanding the metabolism of polyphenols. Anal. Bioanal. Chem. 2010, 398, 463-475. [CrossRef] [PubMed]

36. De la Torre, R. Bioavailability of olive oil phenolic compounds in humans. Inflammopharmacology 2008, 16, 245-247. [CrossRef] [PubMed]

37. Selma, M.V.; Espin, J.C.; Tomas-Barberan, F.A. Interaction between phenolics and gut microbiota: Role in human health. J. Agric. Food Chem. 2009, 57, 6485-6501. [CrossRef] [PubMed]

38. Corona, G.; Spencer, J.; Dessi, M. Extra virgin olive oil phenolics: Absorption, metabolism, and biological activities in the GI tract. Toxicol. Ind. Health 2009, 25, 285-293. [CrossRef] [PubMed]

39. Catalán, Ú.; López de las Hazas, M.C.; Rubió, L.; Fernández-Castillejo, S.; Pedret, A.; la Torre, R.; Motilva, M.J.; Solà, R. Protective effect of hydroxytyrosol and its predominant plasmatic human metabolites against endothelial dysfunction in human aortic endothelial cells. Mol. Nutr. Food Res. 2015, 59, 2523-2536. [CrossRef] [PubMed]

40. Kotas, M.E.; Medzhitov, R. Homeostasis, Inflammation, and Disease Susceptibility. Cell 2015, 160, 816-827. [CrossRef] [PubMed]

41. Perez-Herrera, A.; Delgado-Lista, J.; Torres-Sanchez, L.; Rangel-Zuñiga, O.; Camargo, A.; Moreno-Navarrete, J.; Garcia-Olid, B.; Quintana-Navarro, G.; Alcala-Diaz, J.; Muñoz-Lopez, C. The postprandial inflammatory response after ingestion of heated oils in obese persons is reduced by the presence of phenol compounds. Mol. Nutr. Food Res. 2012, 56, 510-514. [CrossRef] [PubMed]

42. Moreno-Luna, R.; Muñoz-Hernandez, R.; Miranda, M.L.; Costa, A.F.; Jimenez-Jimenez, L.; Vallejo-Vaz, A.J.; Muriana, F.J.; Villar, J.; Stiefel, P. Olive oil polyphenols decrease blood pressure and improve endothelial function in young women with mild hypertension. Am. J. Hypertens. 2012, 25, 1299-1304. [CrossRef] [PubMed]

43. Bogani, P.; Galli, C.; Villa, M.; Visioli, F. Postprandial anti-inflammatory and antioxidant effects of extra virgin olive oil. Atherosclerosis 2007, 190, 181-186. [CrossRef] [PubMed]

44. Urpi-Sarda, M.; Casas, R.; Chiva-Blanch, G.; Romero-Mamani, E.S.; Valderas-Martínez, P.; Arranz, S.; Andres-Lacueva, C.; Llorach, R.; Medina-Remón, A.; Lamuela-Raventos, R.M. Virgin olive oil and nuts as key foods of the Mediterranean diet effects on inflammatory biomarkers related to atherosclerosis. Pharmacol. Res. 2012, 65, 577-583. [CrossRef] [PubMed]

45. Muto, E.; Dell'Agli, M.; Sangiovanni, E.; Mitro, N.; Fumagalli, M.; Crestani, M.; Fabiani, E.; Caruso, D. Olive oil phenolic extract regulates interleukin-8 expression by transcriptional and posttranscriptional mechanisms in Caco-2 cells. Mol. Nutr. Food Res. 2015, 59, 1217-1221. [CrossRef] [PubMed]

46. Dell'Agli, M.; Fagnani, R.; Galli, G.V.; Maschi, O.; Gilardi, F.; Bellosta, S.; Crestani, M.; Bosisio, E.; De Fabiani, E.; Caruso, D. Olive oil phenols modulate the expression of metalloproteinase 9 in THP-1 cells by acting on nuclear factor-kB signaling. J. Agric. Food Chem. 2010, 58, 2246-2252. [CrossRef] [PubMed]

47. Beauchamp, G.K.; Keast, R.S.; Morel, D.; Lin, J.; Pika, J.; Han, Q.; Lee, C.-H.; Smith, A.B.; Breslin, P.A. Phytochemistry: Ibuprofen-like activity in extra-virgin olive oil. Nature 2005, 437, 45-46. [CrossRef] [PubMed]

48. Iacono, A.; Gómez, R.; Sperry, J.; Conde, J.; Bianco, G.; Meli, R.; Gómez-Reino, J.J.; Smith, A.B.; Gualillo, O. Effect of oleocanthal and its derivatives on inflammatory response induced by lipopolysaccharide in a murine chondrocyte cell line. Arthritis Rheum. 2010, 62, 1675-1682. [CrossRef] [PubMed]

49. Scotece, M.; Gómez, R.; Conde, J.; Lopez, V.; Gómez-Reino, J.J.; Lago, F.; Smith, A.B.; Gualillo, O. Further evidence for the anti-inflammatory activity of oleocanthal: Inhibition of MIP- $1 \alpha$ and IL-6 in J774 macrophages and in ATDC5 chondrocytes. Life Sci. 2012, 91, 1229-1235. [CrossRef] [PubMed]

50. Pitt, J.; Roth, W.; Lacor, P.; Smith, A.B.; Blankenship, M.; Velasco, P.; De Felice, F.; Breslin, P.; Klein, W.L. Alzheimer's-associated A $\beta$ oligomers show altered structure, immunoreactivity and synaptotoxicity with low doses of oleocanthal. Toxicol. Appl. Pharmacol. 2009, 240, 189-197. [CrossRef] [PubMed] 
51. Monti, M.C.; Margarucci, L.; Tosco, A.; Riccio, R.; Casapullo, A. New insights on the interaction mechanism between tau protein and oleocanthal, an extra-virgin olive-oil bioactive component. Food Funct. 2011, 2, 423-428. [CrossRef] [PubMed]

52. Li, W.; Sperry, J.B.; Crowe, A.; Trojanowski, J.Q.; Smith, A.B., III; Lee, V.M.Y. Inhibition of tau fibrillization by oleocanthal via reaction with the amino groups of tau. J. Neurochem. 2009, 110, 1339-1351. [CrossRef] [PubMed]

53. Abuznait, A.H.; Qosa, H.; Busnena, B.A.; El Sayed, K.A.; Kaddoumi, A. Olive-Oil-Derived Oleocanthal Enhances $\beta$-Amyloid Clearance as a Potential Neuroprotective Mechanism against Alzheimer's Disease: In Vitro and in Vivo Studies. ACS Chem. Neurosci. 2013, 4, 973-982. [CrossRef] [PubMed]

54. Qosa, H.; Batarseh, Y.S.; Mohyeldin, M.M.; El Sayed, K.A.; Keller, J.N.; Kaddoumi, A. Oleocanthal enhances amyloid- $\beta$ clearance from the brains of tgswdi mice and in vitro across a human blood-brain barrier model. ACS Chem. Neurosci. 2015, 6, 1849-1859. [CrossRef] [PubMed]

55. Gong, D.; Geng, C.; Jiang, L.; Cao, J.; Yoshimura, H.; Zhong, L. Effects of hydroxytyrosol-20 on carrageenan-induced acute inflammation and hyperalgesia in rats. Phytother. Res. 2009, 23, 646-650. [CrossRef] [PubMed]

56. Granados-Principal, S.; Quiles, J.L.; Ramirez-Tortosa, C.; Camacho-Corencia, P.; Sanchez-Rovira, P.; Vera-Ramirez, L.; Ramirez-Tortosa, M. Hydroxytyrosol inhibits growth and cell proliferation and promotes high expression of sfrp4 in rat mammary tumours. Mol. Nutr. Food Res 2011, 55, S117-S126. [CrossRef] [PubMed]

57. Scoditti, E.; Nestola, A.; Massaro, M.; Calabriso, N.; Storelli, C.; de Caterina, R.; Carluccio, M.A. Hydroxytyrosol suppresses MMP-9 and COX-2 activity and expression in activated human monocytes via PKC $\alpha$ and PKC $\beta 1$ inhibition. Atherosclerosis 2014, 232, 17-24. [CrossRef] [PubMed]

58. Han, J.; Talorete, T.P.; Yamada, P.; Isoda, H. Anti-proliferative and apoptotic effects of oleuropein and hydroxytyrosol on human breast cancer MCF-7 cells. Cytotechnology 2009, 59, 45-53. [CrossRef] [PubMed]

59. Chimento, A.; Casaburi, I.; Rosano, C.; Avena, P.; De Luca, A.; Campana, C.; Martire, E.; Santolla, M.F.; Maggiolini, M.; Pezzi, V. Oleuropein and hydroxytyrosol activate GPER/GPR30-dependent pathways leading to apoptosis of ER-negative SKBR3 breast cancer cells. Mol. Nutr. Food Res. 2014, 58, 478-489. [CrossRef] [PubMed]

60. Akl, M.R.; Ayoub, N.M.; Mohyeldin, M.M.; Busnena, B.A.; Foudah, A.I.; Liu, Y.-Y.; Sayed, K.A.E. Olive phenolics as c-Met inhibitors: (-)-oleocanthal attenuates cell proliferation, invasiveness, and tumor growth in breast cancer models. PLoS ONE 2014, 9, e97622. [CrossRef] [PubMed]

61. Scotece, M.; Gómez, R.; Conde, J.; Lopez, V.; Gomez-Reino, J.; Lago, F.; Smith, I.; Gualillo, O. Oleocanthal inhibits proliferation and MIP-1 $\alpha$ expression in human multiple myeloma cells. Curr. Med. Chem. 2013, 20, 2467-2475. [CrossRef] [PubMed]

62. LeGendre, O.; Breslin, P.A.; Foster, D.A. (-)-Oleocanthal rapidly and selectively induces cancer cell death via lysosomal membrane permeabilization. Mol. Cell. Oncol. 2015, 2, e1006077. [CrossRef] [PubMed]

63. Fogli, S.; Arena, C.; Carpi, S.; Polini, B.; Bertini, S.; Digiacomo, M.; Gado, F.; Saba, A.; Saccomanni, G.; Breschi, M.C.; et al. Cytotoxic Activity of Oleocanthal Isolated from Virgin Olive Oil on Human Melanoma Cells. Nutr. Cancer 2016, 68, 873-877. [CrossRef] [PubMed]

64. Khanfar, M.A.; Bardaweel, S.K.; Akl, M.R.; El Sayed, K.A. Olive Oil-derived Oleocanthal as Potent Inhibitor of Mammalian Target of Rapamycin: Biological Evaluation and Molecular Modeling Studies. Phytother. Res. 2015, 29, 1776-1782. [CrossRef] [PubMed]

65. Warnke, I.; Goralczyk, R.; Fuhrer, E.; Schwager, J. Dietary constituents reduce lipid accumulation in murine C3H10 T1/2 adipocytes: A novel fluorescent method to quantify fat droplets. Nutr. Metab. 2011, 8, 1-13. [CrossRef] [PubMed]

66. Drira, R.; Chen, S.; Sakamoto, K. Oleuropein and hydroxytyrosol inhibit adipocyte differentiation in 3 T3-L1 cells. Life Sci. 2011, 89, 708-716. [CrossRef] [PubMed]

67. Scoditti, E.; Massaro, M.; Carluccio, M.A.; Pellegrino, M.; Wabitsch, M.; Calabriso, N.; Storelli, C.; de Caterina, R. Additive Regulation of Adiponectin Expression by the Mediterranean Diet Olive Oil Components Oleic Acid and Hydroxytyrosol in Human Adipocytes. PLoS ONE 2015, 10, e0128218. [CrossRef] [PubMed] 
68. González-Santiago, M.; Martín-Bautista, E.; Carrero, J.J.; Fonollá, J.; Baró, L.; Bartolomé, M.V.; Gil-Loyzaga, P.; López-Huertas, E. One-month administration of hydroxytyrosol, a phenolic antioxidant present in olive oil, to hyperlipemic rabbits improves blood lipid profile, antioxidant status and reduces atherosclerosis development. Atherosclerosis 2006, 188, 35-42. [CrossRef] [PubMed]

69. Pei, T.; Meng, Q.; Han, J.; Li, H.; Song, R.; Sun, B.; Pan, S.; Liang, D.; Liu, L. (-)-Oleocanthal inhibits growth and metastasis by blocking activation of STAT3 in human hepatocellular carcinoma. Oncotarget 2016, 7, 43475-43491. [CrossRef] [PubMed]

70. Sepporta, M.V.; Fuccelli, R.; Rosignoli, P.; Ricci, G.; Servili, M.; Morozzi, G.; Fabiani, R. Oleuropein inhibits tumour growth and metastases dissemination in ovariectomised nude mice with MCF-7 human breast tumour xenografts. J. Funct. Foods 2014, 8, 269-273. [CrossRef]

71. Goulas, V.; Exarchou, V.; Troganis, A.N.; Psomiadou, E.; Fotsis, T.; Briasoulis, E.; Gerothanassis, I.P. Phytochemicals in olive-leaf extracts and their antiproliferative activity against cancer and endothelial cells. Mol. Nutr. Food Res. 2009, 53, 600-608. [CrossRef] [PubMed]

72. Van Golen, K.L.; Wei Bao, L.; Pan, Q.; Miller, F.R.; Fen Wu, Z.; Merajver, S.D. Mitogen activated protein kinase pathway is involved in RhoC GTPase induced motility, invasion and angiogenesis in inflammatory breast cancer. Clin. Exp. Metastasis 2002, 19, 301-311. [CrossRef] [PubMed]

73. Hay, N.; Sonenberg, N. Upstream and downstream of mTOR. Genes Dev. 2004, 18, 1926-1945. [CrossRef] [PubMed]

74. Ruano, J.; Lopez-Miranda, J.; Fuentes, F.; Moreno, J.A.; Bellido, C.; Perez-Martinez, P.; Lozano, A.; Gómez, P.; Jiménez, Y.; Pérez Jiménez, F. Phenolic Content of Virgin Olive Oil Improves Ischemic Reactive Hyperemia in Hypercholesterolemic Patients. J. Am. Coll. Cardiol. 2005, 46, 1864-1868. [CrossRef] [PubMed]

75. Covas, M.-I.; de la Torre, K.; Farré-Albaladejo, M.; Kaikkonen, J.; Fitó, M.; López-Sabater, C.; Pujadas-Bastardes, M.A.; Joglar, J.; Weinbrenner, T.; Lamuela-Raventós, R.M.; et al. Postprandial LDL phenolic content and LDL oxidation are modulated by olive oil phenolic compounds in humans. Free Radic. Biol. Med. 2006, 40, 608-616. [CrossRef] [PubMed]

76. Konstantinidou, V.; Covas, M.-I.; Muñoz-Aguayo, D.; Khymenets, O.; de la Torre, R.; Saez, G.; Tormos, M.d.C.; Toledo, E.; Marti, A.; Ruiz-Gutiérrez, V.; et al. In vivo nutrigenomic effects of virgin olive oil polyphenols within the frame of the Mediterranean diet: A randomized controlled trial. FASEB J. 2010, 24, 2546-2557. [CrossRef] [PubMed]

77. Hernáez, Á.; Remaley, A.T.; Farràs, M.; Fernández-Castillejo, S.; Subirana, I.; Schröder, H.; Fernández-Mampel, M.; Muñoz-Aguayo, D.; Sampson, M.; Solà, R.; et al. Olive Oil Polyphenols Decrease LDL Concentrations and LDL Atherogenicity in Men in a Randomized Controlled Trial. J. Nutr. 2015, 145, 1692-1697. [CrossRef] [PubMed]

78. Weinbrenner, T.; Fitó, M.; De La Torre, R.; Saez, G.T.; Rijken, P.; Tormos, C.; Coolen, S.; Albaladejo, M.F.; Abanades, S.; Schroder, H. Olive oils high in phenolic compounds modulate oxidative/antioxidative status in men. J. Nutr. 2004, 134, 2314-2321. [PubMed]

79. Gimeno, E.; de la Torre-Carbot, K.; Lamuela-Raventós, R.M.; Castellote, A.I.; Fitó, M.; de la Torre, R.; Covas, M.-I.; López-Sabater, M.C. Changes in the phenolic content of low density lipoprotein after olive oil consumption in men. A randomized crossover controlled trial. Br. J. Nutr. 2007, 98, 1243-1250. [CrossRef] [PubMed]

80. Cao, K.; Xu, J.; Zou, X.; Li, Y.; Chen, C.; Zheng, A.; Li, H.; Li, H.; Szeto, I.M.-Y.; Shi, Y. Hydroxytyrosol prevents diet-induced metabolic syndrome and attenuates mitochondrial abnormalities in obese mice. Free Radic. Biol. Med. 2014, 67, 396-407. [CrossRef] [PubMed]

81. Ruano, J.; López-Miranda, J.; de la Torre, R.; Delgado-Lista, J.; Fernández, J.; Caballero, J.; Covas, M.I.; Jiménez, Y.; Pérez-Martínez, P.; Marín, C. Intake of phenol-rich virgin olive oil improves the postprandial prothrombotic profile in hypercholesterolemic patients. Am. J. Clin. Nutr. 2007, 86, 341-346. [PubMed]

(C) 2016 by the authors; licensee MDPI, Basel, Switzerland. This article is an open access article distributed under the terms and conditions of the Creative Commons Attribution (CC-BY) license (http://creativecommons.org/licenses/by/4.0/). 